\title{
Determinant of Residential Property Price Index in Five Asian Emerging Market Countries: A Demand and Supply Approach
}

\author{
Silma Fikria Balqis ,Rudi Purwono
}

\author{
Universitas Airlangga
}

Corresponding : rudipurwono@feb.unair.a c.id

Received: 14, August, 2021

Accepted: 22, August, 2021

Published: 31August 2021

\begin{abstract}
This study aims to analyze the factors influencing the Residential Property Price Index (RPPI) from the demand and supply sides in five Asian emerging market countries. The data used are semi-annual data from the first semester of 2009 until the second semester of 2019 because this study aims to denote the impact of RPPI toward the demand and supply indicators after the global crisis in 2008. The dependent variable of this study is the RPPI, while the independent variables include the number of workers, real interest rate, economic growth, and the Real Effective Exchange Rate (REER). The Fixed Effects Model (FEM) is thus the applied method to process the data. In the end, the results indicate that all independent variables are significant toward the RPPI. The number of workers, real interest rate, and REER negatively affect the RPPI, while economic growth positively affects the RPPI.
\end{abstract}

Keywords: Residential Property Price Index, Property Demand, Property Supply, Asian Emerging Market, Fixed Effects Model

\section{Introduction}

The population of a country always increases every year, which subsequently increases the need for the property. This proves that the property market has an extensive role in economic performance and is impactful on individual welfare (Latif, et al., 2015). Buying a house is the biggest investment any household can make. Moreover, the return of investment in a house has a greater wealth effect than any other financial asset. A house, additionally, is arguably the single largest item of everyone's wealth, given the changes in house prices can highly affect the economy and consumer spending (Anundsen, et al., 2016).

House prices can be monitored from the supply and demand sides. The former refers to the property development side. The overly high house prices can trigger a crisis in the financial sector, given buyers with a credit system will have difficulty paying; therefore, the default will consequently cause a problem in the financial sector (Cohen \& Karpavičiūte, 2017). The latter, in addition, is the property buyer side. In other words, high property demand coupled with speculations can lead to the rapid increase in the Residential Property Price Index (hereafter, RPPI). If the RPPI continuously rises, in consequence, conditions such as a property bubble may also occur (Amador-Torres, et al., 2018).

A property bubble is a condition where the property or house price unreasonably escalates, which at a certain point reaches the pricing climax before the price falls significantly. This fall in property prices will generate a recession in the national economy since the majority of house-buying is funded by loans from financial institutions, and property is used as the main collateral asset for bank loans (Amador-Torre, et al., 2018). The demand side is arguably the main cause of the property bubble. Hence, the public and policymakers must monitor house prices. A property bubble, moreover, is a risk that arises due to the changes in house prices. Therefore, house price risk has attracted a lot of attention in recent years.

According to Kaulihowa and Kamati (2019), several industrial countries, including the United States, the United Kingdom, and Spain, lately have experienced a significant increase in house prices, which among the risks is the slowdown in housing loans. This happens since house prices continue to rise from time to time, and therefore it is analyzed further. Due to that reason, an analysis of the house price in five Asian emerging market countries also needs to be carried out. A country is categorized as an emerging market if its economy is developing, its industry is rapidly growing, and it has high economic growth. The countries belonging to the emerging markets are considered to have a greater potential than other developing countries (MSCI, 2021). Thus, this study uses emerging market countries intending to observe the indicators that affect the RPPI in those countries, in particular by referring to the study conducted by Kishor and Marfatia (2017) who concluded that every country responds to the RPPI indicators differently depending on the country's economic conditions. 


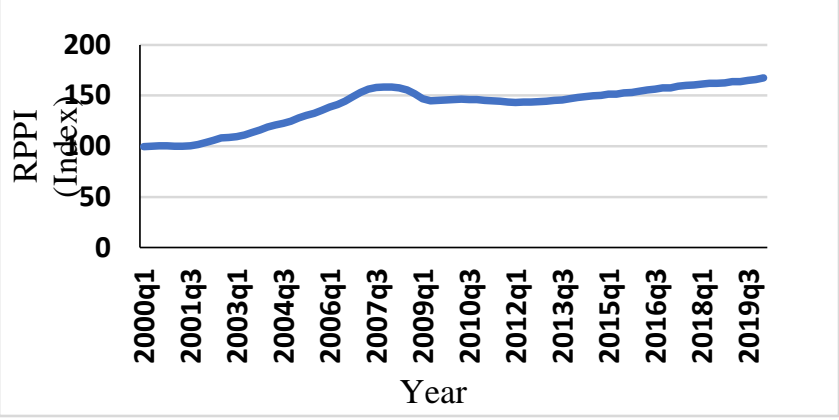

Figure 1.1 The Residential Property Price Index in Emerging Market Countries

Source: Bank for International Settlement (2021)

Figure 1.1 displays the RPPI in emerging market countries, which implies that it grows every year. The prominent upsurge, furthermore, occurred in 2008 when the global crisis took place. In other words, the figure signifies that the emerging market countries were highly affected by the 2008 crisis. MSCI (2021) stated that in total, there are fifty emerging market countries. Meanwhile, this study only employed five emerging market countries in Asia, namely China, Indonesia, Korea, Malaysia, and Thailand, in which the housing market conditions are almost similar. Furthermore, the escalation in house prices in those five countries is stable every year. The Bank of International Settlement (2021) further confirmed that among the five countries, Malaysia has the highest house price.

Amador-Torres, et al. (2018) argued that the house price increase is due to the house price movements affected by movements in macroeconomic variables. Each country, additionally, responds to the movements in macroeconomic variables to the RPPI in various ways, depending on the economic conditions and policies of the country. According to Kok, et al. (2018) and Chi-Weis et al. (2019), the real Gross Domestic Product (GDP) is a macroeconomic variable with a major role in affecting the housing market movement. On the other hand, Strobel, et al. (2018) suggested that the number of workers is one of the house price determinants. The number of workers, furthermore, is associated with higher income; therefore, higher employment rises the housing demand and house prices. Agnew and Lyons (2018) also added that the number of workers has a positive relationship with the RPPI.

An increase in the real interest rate leads to an increase in the borrowing cost and a decrease in the housing demand. Studies denote that interest rate is one of the most prominent macroeconomic factors affecting the housing market (Kishor \& Marfatia, 2017; Nistor \& Reianu, 2018). The argument is generated by the increasing availability of bank credit, which can lead to the escalation in the housing loan demand in line with lower interest rates. As a result, the housing demand will grow, which also increases house prices.

The exchange rate is a noteworthy factor to evaluate the current condition and future projections of the property industry, specifically in developing countries (Sumer \& Ozorhon, 2021). Consequently, the relationship between property prices and exchange rates has always been a crucial issue, notably due to the concerns regarding the impacts of imported goods. The changes in exchange rates further affect the house prices since the pressured domestic exchange rate leads to the increasing import cost of some construction materials and equipment. In other words, it implies that the depreciation of domestic exchange causes an increase in house prices. Asal (2018) also added that the Real Effective Exchange Rate (REER) has a negative impact on the RPPI. Vogiazas (2017), however, argued that the REER positively affects the RPPI. Thus, it can be denoted that the REER as a variable in studies has different impacts on the RPPI.

Based on the background previously elucidated, it can be remarked that there are differences in both the results and independent variables used due to differences in economic levels, research methods utilized, and other indicators owned by the respective countries. Hence, this study is conducted under the title "Determinant of Residential Property Price Index in terms of Demand and Supply in Five Asian Emerging Market Countries," with the RPPI as the dependent variable and the number of workers, real interest rate, economic growth, and the Real Effective Exchange Rate (REER) as the independent variables. The method used, moreover, is the Fixed Effects Model (FEM).

\section{Literature Review}

\subsection{Theoretical Framework}

\subsubsection{The Theory of Demand}

Demand is one's need for goods, services, or everything that the person wants. The law of demand suggests a negative relationship between the quantity of the demanded goods and the goods price. Demand for needs in the market is not only influenced by price, but also by quality and substitute goods (Dornbusch, et al., 2008:108).

Price changes will affect demand, which is also commonly known as the price elasticity of demand. According to this theory, someone will buy less when the price increases. Even so, the goods price can rise without reducing the demand level, which also means that prices are inelastic.

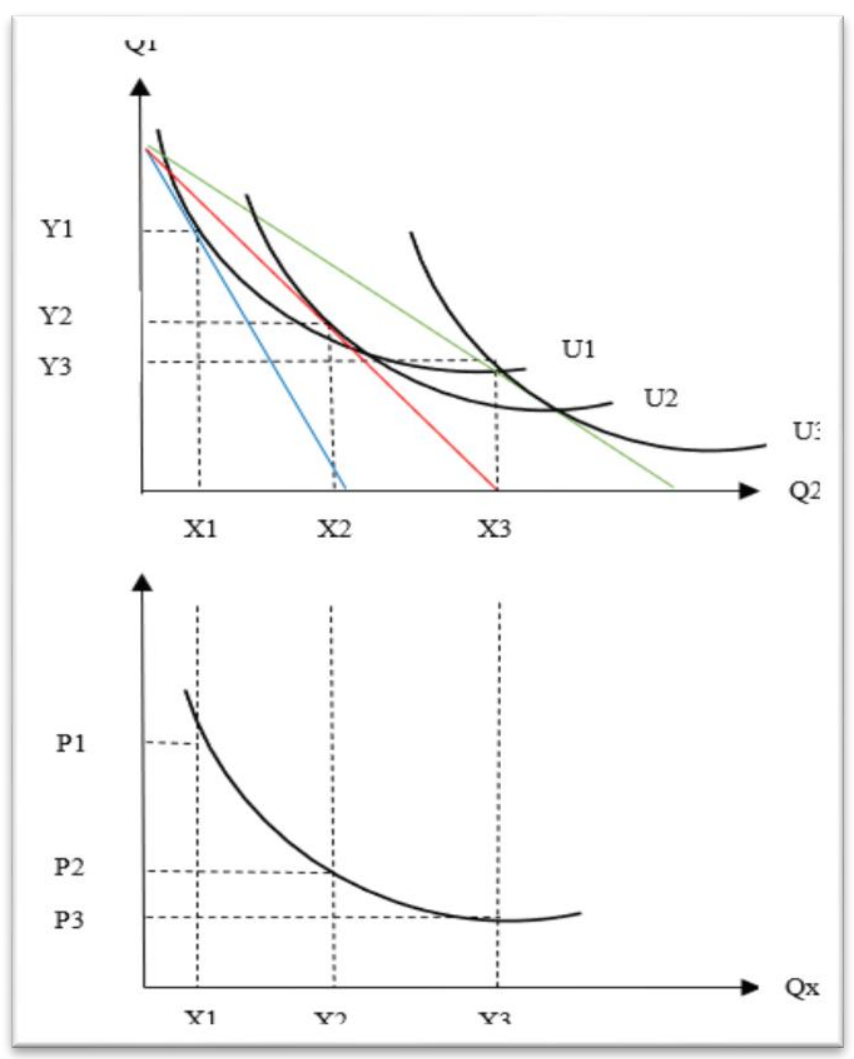

Figure 2.1 The Indifference Curves

Source: Nicholson \& Synder (2012) 
Figure 2.1 is a demand curve derived from an indifference curve, which is a combination where an individual buys a good that can be substituted. In Figure 2.1, Y-axis represents goods Y, while Xaxis indicates goods $\mathrm{X}$, wherein Utility 1 (U1), goods $\mathrm{Y}$ is more than goods $\mathrm{X}$. To obtain the same utility, namely in $\mathrm{U} 2$, goods $\mathrm{Y}$ is reduced and goods $\mathrm{X}$ is added, and likewise in U3. The reduction in the demand curve comes from the maximum utility level that can be reached by each individual. Additionally, when the price of goods X decreases, its demand increases.

\subsubsection{The Theory of Supply}

Samuelson and Nordhaus (2009:51) explained that the supply curve is related to the goods' price in the market and the number of commodities produced and sold. The supply curve is upward sloping due to the application of The Law of Diminishing Returns. The law of supply states that "the price of an item goes up if the quantity of the supplied goods increases and vice versa." The law of supply further asserts the directly proportional relationship between the quantity of supplied goods and the price level. The supply curve can be affected by several factors, such as 1) the production cost determined by input prices and technological progress; 2) related goods price; 3) government policies; and 4) certain influences, namely weather, market structures, future prices expectations, and so on.

Furthermore, the number of goods offered is also influenced by other factors than the price itself due to the shift in supply changes, thereby shifting the supply curve (shift in supply). In other words, if the supply escalates, the supply curve will shift to the right, causing the price to decline and the quantity of goods to rise. Conversely, if the supply decreases, the supply curve will shift to the left, thereby the price escalates and the quantity of goods decreases (Samuelson \& Nordhaus, 2009:57).

\subsubsection{The Theory of Housing Demand}

Brueggeman and Fisher (2011:9) described a house as a basic need for individuals and households. Apart from being used as a place to live, a house is also utilized as an investment means to accumulate personal wealth. A house, moreover, can be considered as consumer goods (residence) and investment. One of the factors affecting housing as investments is the rates of price appreciation and depreciation along with things generating the house price movement.

House prices are highly affected by housing demands, including population, the number of workers or households, and income. Moreover, interest rates also bring negative impacts on the house price movements. The increasing housing demands will amplify the construction of new houses, thereby the house prices will also rise. In addition, when the demand for housing shifts, it will be followed by the housing supply (Brueggeman \& Fisher, 2011:13).

Pontiggia and Sivitanides (2020) believed that the macroeconomic determinants of house prices comprise demand and supply functions, which can be represented as follows:

$$
\begin{aligned}
& \mathrm{D}_{\mathrm{t}}=\mathrm{F}\left(\mathrm{P}_{\mathrm{t}}, \mathrm{INC}_{\mathrm{t}}, \mathrm{X \backslash \textrm {t }}\right) \ldots \ldots \ldots(2.1) \\
& \mathrm{S}_{\mathrm{t}}=\mathrm{F}\left(\mathrm{P}_{\mathrm{t}}, \mathrm{Y}_{\mathrm{t}}\right) \ldots \ldots \ldots \ldots \ldots(2.2) \\
& \text { where } \\
& \mathrm{Dt} \quad: \text { Demand for houses } \\
& \mathrm{St} \quad: \text { Supply of houses } \\
& \mathrm{Pt} \quad: \text { House price }
\end{aligned}
$$

INCt : Household, per capita income, or GDP

$\mathrm{Xt}$ : Vector of other exogenous factors that drive the demand for houses
Yt : Vector of other exogenous factors that drive the supply of houses

$\mathrm{Xt}$ consists of the number of households, population, total employment, and capital cost variables, such as interest rates. Pontiggia and Sivitanides (2020) further asserted that a higher number of households, population, or total employment, along with lower interest rates will increase housing demands.

By equating demand and supply, the solution to the general form of house price equation is thus:

$\mathrm{Pt}=\mathrm{f}(\mathrm{INCt}, \mathrm{HLt}, \mathrm{Xt}, \mathrm{Yt})$

where

INCt : Household, per capita income, or GDP

HLt : Housing loans

$\mathrm{Xt}$ : Vector of other exogenous factors that drive the demand for houses

Yt : Vector of other exogenous factors that drive the supply of houses

In addition to housing, individuals also make a house as a longterm investment, given a house itself is a non-tradeable asset. Property investment is divided into two types, namely residential and non-residential. The former refers to the single-family and multi-properties, while the latter points out buildings that are not used as residences.

Both residential investment and business investment have a similar model; however, business investment is explained by using Tobin's Q Ratio. According to the theory, business investment depends on the market price of installed capital relative to its replacement cost; while residential investment depends on the housing relative prices. Housing relative prices, furthermore, rely upon the demand for rent that people expect when renting their houses. Thus, it can be stated that housing relative prices play a similar role to residential investment as Tobin's Q ratio to business investment (Mankiw, 2007). When housing demand shifts, the housing equilibrium price will also shift, which affects residential investment. The shifts in the demand curve for housing can be initiated for several reasons. In addition, the booming economy increases national income and housing demands. The residential investment model is pictured in Figure 2.2.

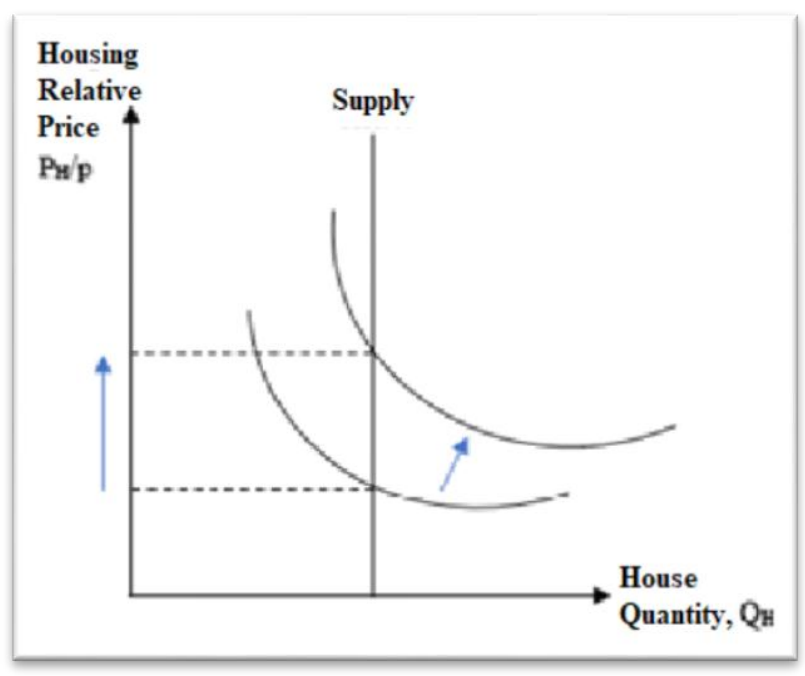

Figure 2.2 Housing Supply Curve

Source: Mankiw (2007)

Based on expansionary shifts in demand that amplify the equilibrium price, housing shifts occur due to the escalation in the 
national income and population growth. One determinant of housing demand, in addition, is the reduction in interest rates, thereby the increase in prices and residential investment (Mankiw, 2007)

A surge in demand will generate an increase in housing supply, which then leads to an escalation in the development of new houses. Hence, the market prices move at a higher point. Meanwhile, the decline in housing demand will result in an opposite shift in the demand curve and house prices fall in the equilibrium market (Brueggemam \& Fisher, 2011).

\subsubsection{Property Cycle}

Mankiw (2007:246) stated that the business cycle is a type of fluctuation found in countries' aggregate economic activity that regulates the countries' work, particularly in business enterprises. A cycle includes expansions that occur roughly at the same time in several economic activities, followed by a recession, contraction, and revival that merge into an expansion phase of the next cycle where the sequence of these changes is repetitive but not periodic.

The duration of a business cycle varies from more than one year to ten or twelve years, where it is not divided into shorter cycles with characters similar to the amplitudes that are close to their capabilities. Leamer (2015) affirmed that housing is one of the most prominent parts of a business cycle. Therefore, housing creates a cycle called the property cycle. The property cycle, furthermore, is a pattern in the property market that has three different phases, namely boom, slump, and recovery. The boom phase is followed by the slump phase before entering the recovery phase ahead of the next boom. A general property cycle will follow the pattern, in which a boom phase does not overtake another without experiencing a slump and recovery. When the boom phase begins, most people believe that it is merely a short-term anomaly that will not last long because they do not have a full comprehension of this cycle.

\subsubsection{The Number of Workers}

The term "employment" in English is derived from the verb "to employ," which means to use in a process or an effort to provide work or a source for living. Hence, employment can be defined as a state of people who are having jobs. The use of the term "employment" is further specified as many people who have jobs and belong to the workforce (Borjas, 2010:86).

The workforce is the population who have reached working age, whether they are already working, not yet working, or looking for a job. Meanwhile, workers are the population who are of working age, working or actively looking for a job, and are still willing and able to work. The labor employment, additionally, is the number of workers employed in the economic sector (primary, secondary, and tertiary) within a certain period. The number of employed workers is determined by the demand for labor in economic activity. The workers employed by the economic sector of a country, thus, will contribute to the increase in the country's income.

\subsubsection{Real Interest Rate}

Mankiw (2006:89) defined real interest rate as the interest that has been adjusted for inflation. The equation for the real interest rate is:
The interest rate, meanwhile, is related to the level of lending. Credit interest rates affect the amount of credit financing made by consumers or developers in providing housing. Interest rates also affect house prices through the level of distributed credit.

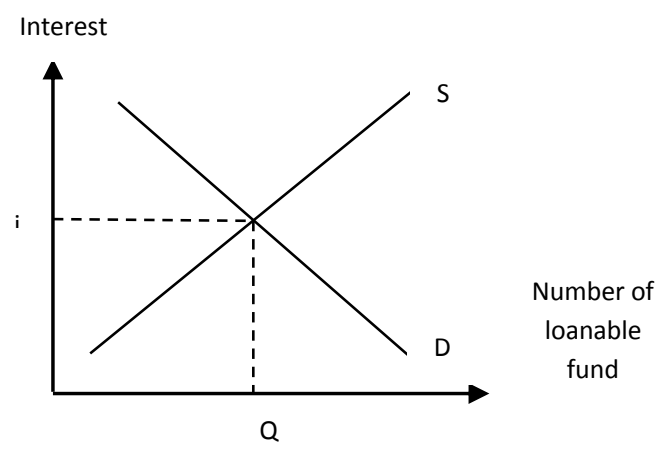

Figure 2.3 The Loanable Fund Theory

Source: Mishkin, 2015

The graph in Figure 2.3 displays the relationship between interest rates and the number of loanable funds based on the classical theory. The classics argued that interest rates have a negative relationship with the demand of loanable funds (investment) and a positive relationship with the supply of loanable funds (savings). In other words, the escalation in credit interest rates can increase the credit supply. On the other hand, the rise in the interest rates can decrease the credit demand (Mishkin, 2015:900).

\subsubsection{Economic Growth}

The economic growth of each country is measured by Gross Domestic Product (GDP). GDP summarizes the economic activities of a country which can be seen from the total income on the output of the economic goods and the services (Mankiw, 2007:18). The increase in economic growth, furthermore, has become a positive signal to increase investment in the credit sector.

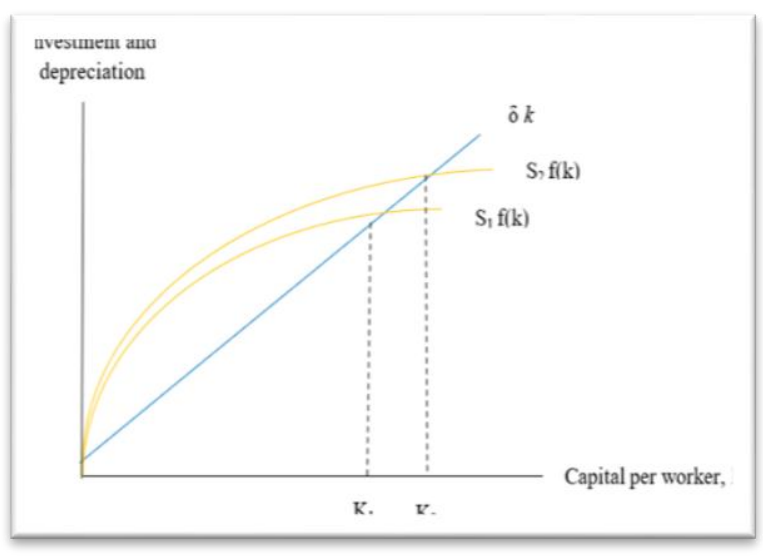

Figure 2.4 The Solow Model

Source: Mankiw, 2007

Investment is one of the conditions for a country's economy to grow and develop. This theory is further developed into the Solow Model, which asserted that when the average saving of a country increases, the economy will have large capital and a high output level. In other words, when the average saving is low, then, the economy will have a low output level (Mankiw, 2007:221). The Solow Model can be used as pictured in Figure 2.4. 


\subsubsection{The Real Effective Exchange Rate}

According to Bank Indonesia (2017), the Real Effective Exchange Rate (REER) is an indicator to explain the value of a currency to other countries' currencies that have been adjusted to the inflation rate in certain years or certain consumer price index.

Generally, the REER is employed to measure a country's competitiveness. The escalation of REER depicts the higher export rate and the lower import rate, which also implies the decrease in trade competitiveness, and vice versa. The REER can be identified by dividing the domestic price level by the foreign price level that has been multiplied by the nominal effective exchange rate. In other words, the increase in REER can be used as a conclusion whether a country is undergoing a decline in trade competitiveness

$R E E R_{t}=\Pi\left\{\frac{\left(C U R_{i} / C U R_{t}\right)}{\left(C U R_{0} / C U R_{0}\right)}\right\}^{w i}+\left\{\frac{\left(P_{i d} / P_{i}\right)}{\left(P_{i d} / P_{i}\right)}\right\}^{w i}$

$\begin{array}{ll}\text { REER } & : \text { Real Effective Exchange Rate in } t \text { period } \\ \text { CUR } & : \text { Foreign currency } \\ \text { IDR } & : \text { Domestic currency } \\ \mathrm{P} & : \text { Price index } \\ \mathrm{t} & : t \text { period } \\ \mathrm{W} & : \text { Weight } \\ \mathrm{O} & : \text { Base year } \\ \mathrm{i} & : \text { Foreign country } \\ \mathrm{id} & : \text { Domestic country }\end{array}$

\subsection{Previous Studies}

Nistor and Reianu (2018) in their study aimed to analyze the determinants of house prices with a focus to investigate the effects of immigrants in the ten largest urban areas in Ontario, Canada, in 2001-2011. The current study, meanwhile, uses five Asian emerging market countries whose category is based on developing countries attempting to be developed countries. In terms of methods, Nistor and Reianu (2018) employed the Partial Least Square (PLS) panel method with the number of immigrants, interest rates, income, and unemployment as the variables. As a result, they discovered that immigrants and income had positive impacts on the RPPI, while interest rates and unemployment negatively affected the RPPI.

The second study was carried out by Vogiazas and Alexiou (2017). By using the generalized method of moments (GMM), their study had an objective to scrutinize the relationship between residential property prices and business cycles in seven developed countries, which was determined by the increase in real house prices of more than 50\% in 2000-2015 using quarterly data. Meanwhile, this present study uses the FEM method. In their study, Vogiazas and Alexiou (2017) used several variables, namely real GDP, credit growth, long-term bond yields, and the REER. Eventually, they confirmed that credit growth, real economic growth, and the REER positively affected house prices, both in the short term and in the long term. On the contrary, long-term and short-term bond yields had negative impacts on house prices.

In another study, Asal (2018) examined the extent to which real house prices are determined by affordability, demography, and asset prices in the short term and long term in Sweden from quartal 1 of 1986 (1986q1) until quartal 4 of 2016 (2016q4). Some variables, including real house prices, real disposable income, interest rates after tax, the REER, population, real disposable income, and unemployment, were analyzed by applying the Vector Error Correction Model (VECM). After analyzing all variables, Asal (2018) confirmed that the REER, unemployment, and interest rates had negative impacts on both the long-term and the shortterm house prices. On the contrary, positive impacts on house prices were shown by real disposable income and population.

The next study was conducted by Panagiotidis and Printzis (2016), who pondered the role of the housing market in the Greek economy. The results of their study indicated the interdependence between the property price index and macroeconomic determinants under the VECM framework. Moreover, they found that in the long term, the retail sector and loans were the most prominent variables for housing. In the short term, however, lending rates, consumer price index (CPI), and Granger retail might affect the House Price Index (HPI). The decomposition variants further showed that the HPI responded to loan shocks, while shocks to the market index did not significantly affect the HPI.

Ultimately, Li, et al. (2018) also conducted a study on a similar topic. Their study concluded that GDP, disposable income, money supply, and interest rates as variables indeed affected house prices. Additionally, GDP had a strong correlation with house prices and, at the same time, long-term positive effects. Disposable income as another variable was positively and strongly correlated with house prices, and so did money supply. Interest rates, however, were found to negatively affect house prices.

\section{Research Methods}

\subsection{Research Approach}

This present study utilized a quantitative approach that employed a panel data regression method with Stata 13 as the analytics tool. Gujarati (2012) defined panel data as a combination of crosssection and time-series data that can provide more data so that it affects a greater degree of freedom as one of its advantages. The combination is also considered to be able to overcome the issues generated due to the removal of the dropped variable. This study particularly employed the cross-section data of five Asian emerging market countries, namely China, Indonesia, Korea, Malaysia, and Thailand. The data was semi-annual data from the first semester of $2009(2009 \mathrm{~s} 1)$ until the second semester of 2019 (2019s2). These periods were chosen to observe the impact of determinants on the RPPI in terms of demand after the global crisis or the recovery phase. The data availability complied with the year closest to the study period, that is 2019 .

The dependent variable of this study is the Residential Property Price Index (RPPI), while the independent variables were the number of workers, real interest rate, economic growth, and the Real Effective Exchange Rate (REER). These independent variables were selected since they are the indicators to measure the RPPI. There were five Asian countries to include in this present study, which aims to analyze the determinants affecting the RPPI in five Asian emerging market countries. The data comprised the cross-section and time-series, and the panel data regression method of FEM was employed using Stata 13 analytics tool.

\subsection{Source of Data}

The quantitative data source of this study was taken using the secondary data collection technique, which the type of the quantitative data was panel data. The data source for the RPPI (100 = 2010) was obtained from the Bank for International Settlement (BIS), while the data for economic growth was gathered from the Federal Reserve Bank of ST. Louis. On the other hand, the data for the REER and the number of workers were acquired from the International Monetary Fund (IMF). Also, the data of the real interest rate processed by reducing inflation was attained from the internal sector of the Economic and Financial Statistics of Bank 
Indonesia, while the data of nominal interest rate was collected from the IMF.

\subsection{The Empirical Model}

This study employed the RPPI as the dependent variable and the number of workers, economic growth, real interest rate, and the REER as the independent variables. The model formulation utilized in this study can be observed from the following equation:

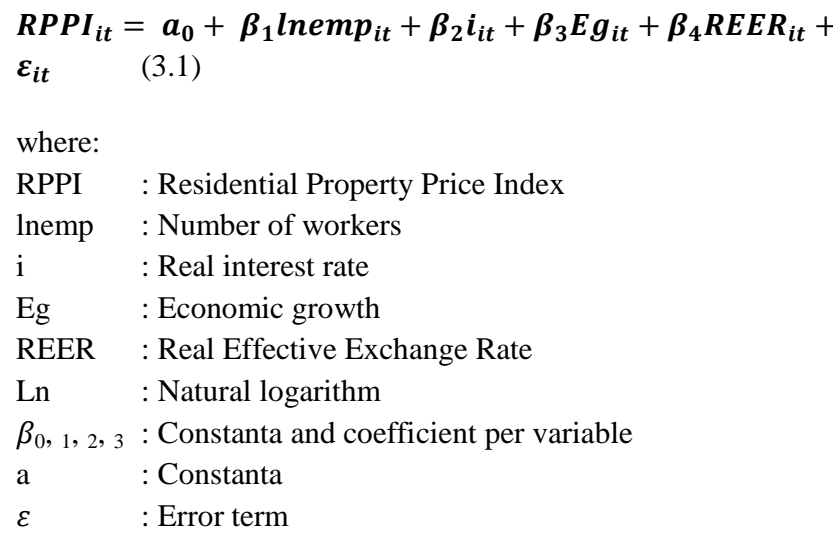

\section{The descriptions of each variable are as follows:}

\section{Residential Property Price Index}

The Residential Property Price Index (RPPI) is a number demonstrating the difference between residential property prices and the number of residential property prices in the base year. The data utilized was the semi-annual data from 2009s1 to 2019s2 obtained from the Bank for International Settlement (BIS). The RPPI data unit is in (index $2010=100$ ).

\section{Number of Workers}

The number of workers is the labor force. The data used was the semi-annual data from 2009s1 to 2019s2 obtained from the International Monetary Fund (IMF). The data unit for the number of workers is in (million people).

\section{Real Interest Rate}

The real interest rate is the key indicator of central bank monetary policy in controlling property purchases. The data of real interest rate for the Asian emerging market countries in 2009s1-2019s2 was acquired from the IMF, then was processed by being multiplied by the inflation of each country obtained from the internal sector of the Economic and Financial Statistics of Bank Indonesia. The data unit is in (percentage (\%)).

\section{Economic Growth}

Economic growth is taken from the real Gross Domestic Product (GDP) growth. GDP is the total added value generated by all business units in a particular country or the total final goods and services produced by all economic units. The data was taken semiannually from 2009s 1 to 2019s 2 from the IMF (in percentage (\%)).

$$
\text { Economic Growth }=\frac{G D P_{t 1}-G D P_{t-1}}{G D P_{t}} \times 100 \%
$$

\section{Real Effective Exchange Rate}

The Real Effective Exchange Rate (REER) is an indicator to explain that the value of a country's currency is relative to several currencies of other countries that have been adjusted for the inflation rate in a certain year or the consumer price index of a particular country. The REER data of the Asian emerging market countries in 2009s1-2019s 2 were gathered from the IMF. The data unit is in (index 2010 $=100$ ).

\subsection{Empirical model}

This study employed a quantitative approach by utilizing the panel data regression method with Stata 13 as the analytics tool. According to Gujarati (2012), panel data is defined as a combination of cross-sectional and time-series data which has several advantages, one of them is it can provide more data so that it affects a greater degree of freedom. Panel data is also a combination of cross-sectional data which can estimate heterogeneity that may emerge in the subjects from time to time. This study employed the cross-sectional data of five emerging market countries, that is Indonesia, Malaysia, Thailand, China, and Korea, and the time series data for the semi-annual periods of 2009s1-2019s2. This study utilized the Fixed Effects Model (FEM) as the analysis method to discover the role of demand on the RPPI.

\subsubsection{The Fixed Effects Model}

The Fixed Effects Model (FEM) is one of the analysis model techniques employed to conduct regression analysis on panel data. This model examines the possible problems of omitted variables in the model that result in changes to the subject and time intercepts. The FEM assumes that the intercept and slope of the model both between cross-sectional and time-series units are constant, although, in reality, the intercepts between subjects from time to time may vary (Gujarati, 2009:596). The problem of heterogeneity, such as differences in culture, institutions, migration, and unobservable regional characteristics, may arise in this study. Therefore, the existing heterogeneity can be solved by using the FEM.

\subsubsection{The Statistical Tests}

Panel data can be analyzed with various models and methods. In selecting the best model in panel data regression, there are two steps of regression test that need to be conducted, namely:

\section{The Chow Test}

The Chow test is a testing technique to determine the most appropriate model between the Common Effects Model (CEM) and the FEM to estimate the panel data. Widarjono (2009) elaborated the hypotheses of the Chow test, as follows:

$\mathrm{H}_{0}$ : The Common Effects Model

$\mathrm{H}_{1}$ : The Fixed Effects Model

$\mathrm{H}_{0}$ is rejected if the $\mathrm{p}$-value is less than $\alpha$ (alpha). The $\alpha$ value used is $5 \%$.

\section{The Hausman Test}

The Hausman test is a simultaneous testing technique to select the most appropriate model between the FEM and the Random Effects Model (REM) in panel data regression. Gujarati (2009:605) explicated the hypotheses of the Hausman test, as follows:

\section{$\mathrm{H}_{0}$ : The Random Effects Model \\ $\mathrm{H}_{1}$ : The Fixed Effects Model}

If the result is statistically significant (the prob $>$ chi $^{2}$ value is less than $\alpha$ ), then $\mathrm{H}_{0}$ is rejected with an $\alpha$ value of $5 \%$. If $\mathrm{H}_{0}$ is rejected, the best model to use is the FEM. Meanwhile, if $\mathrm{H}_{0}$ is accepted, the best model to utilize is the REM.

\section{Findings and Discussion}

\subsection{Estimation Results}




\subsubsection{The Selection of Pooled Least Square(PLS) or Fixed Effect Model(FEM) Estimation Model (The Chow Test)}

The Chow test aims to choose the most appropriate estimation model between PLS and FEM. The hypotheses of the Chow test are as follows:

H0: PLS

H1: FEM

$\alpha=0,05$

\section{Test criteria:}

$\mathrm{H} 0$ is rejected if the Chow test prob value $<0.05$

$\mathrm{H} 0$ is accepted if the Chow test prob value $>0.05$

Then, the conclusion was:

The Chow test prob value $=0.0000$

Therefore, H0 was rejected since the Chow test prob value (0.000) was less than 0.05 , so the model selected was the FEM.

\subsubsection{The Selection of FEM or REM Estimation Model (The Hausman Test)}

The Hausman test aims at deciding the best estimation model between the FEM and the REM. The hypotheses of the Hausman test are as follows:

H0: REM

H1: FEM

$\alpha=0.05$

\section{Test criteria:}

$\mathrm{H} 0$ is rejected if prob $>$ chi2 is less than $\alpha(\alpha=0.05)$

$\mathrm{H} 0$ is accepted if prob $>$ chi2 is more than $\alpha$

Then, the conclusion was:

prob $>$ chi $2=0.0000$

Therefore, H0 was rejected since the prob > chi2 value (0.0000) was less than 0.05 , so the best model chosen was the FEM.

\subsubsection{The Fixed Effects Model}

This study employed panel data to analyze the model, and the method used in this study was the FEM due to the result of the Chow and Hausman tests. The regression results are presented in Table 4.1.

Table 4.1 The FEM Test Results

\begin{tabular}{|l|l|l|l|}
\hline Variable & Coefficient & SE & $\mathbf{p}>|\mathbf{t}|$ \\
\hline Lnemp & $146.275^{*}$ & 12.37656 & 0.000 \\
\hline I & $1.462002^{*}$ & 0.5839916 & 0.014 \\
\hline Eg & 0.4871172 & 0.3492689 & 0.116 \\
\hline REER & -0.1778955 & 0.1088127 & 0.105 \\
\hline Constanta & $-1501.377^{*}$ & 138.4774 & 0.000 \\
\hline No. of observations & 110 & 110 & \\
\hline Prob > f & 0.0000 & 0.0000 & \\
\hline
\end{tabular}

Note : *significant $\alpha=5 \%$

4.1.4 The Classical Assumption Test

1. The Multicollinearity Test
The criterion of multicollinearity test utilizes VIF; there is multicollinearity in the independent variables if the VIF value > 10. Table 4.2 presents the test results using VIF which stated that there was no multicollinearity in the independent variables (VIF < $10)$.

Table 4.2 The Multicollinearity Test Results

\begin{tabular}{|l|l|l|}
\hline Variable & VIF & 1/VIF \\
\hline Lnemp & 120.43 & 0.008304 \\
\hline REER & 85.79 & 0.011656 \\
\hline Eg & 6.83 & 0.0146400 \\
\hline I Heteroscedasticity Test & 4.99 & 0.200518 \\
\hline \multicolumn{2}{|l}{$\mathbf{2}$}
\end{tabular}

The criterion of the heteroscedasticity test is there is a heteroscedasticity problem in the study if the prob > chi2 value was less than $\alpha(\alpha=0.05)$. Table 4.3 demonstrates the heteroscedasticity test results which stated that there was a heteroscedasticity problem in this present study since the prob > chi2 value $(0.0000)$ was less than $\alpha$.

Table 4.3 The Heteroscedasticity Test Results

\begin{tabular}{|l|l|}
\hline Regression Results & RPPI Model \\
\hline $\mathrm{Chi}^{2}(4)$ & 67.56 \\
\hline Prob $>\mathrm{chi}^{2}$ & 0.0000 \\
\hline
\end{tabular}

\section{Autocorrelation Test}

The criterion of the autocorrelation test is there is an autocorrelation problem if the prob $>\mathrm{F}$ value is less than $\alpha(\alpha=$ $0.05)$. 4 displays the autocorrelation test results which indicated that there was an autocorrelation problem in this present study since the prob $>$ F value $(0.0238)$ was less than $\alpha$.

Table 4.4 The Autocorrelation Test Results

\begin{tabular}{|l|l|}
\hline Regression Results & RPPI Model \\
\hline Chi $^{2}(4)$ & 45.736 \\
\hline Prob $>\mathrm{chi}^{2}$ & 0.0025 \\
\hline
\end{tabular}

To eliminate the autocorrelation and heteroscedasticity problems in studies. This present study employed the Panel-corrected Standard Errors (PCSEs) linear regression method, which the results are presented in Table 4.5.

Table 4.5 The Robustness Test Results

\begin{tabular}{|l|l|l|l|}
\hline Variable & Coefficient & SE & $\mathbf{p}>|\mathbf{t}|$ \\
\hline Lnemp & $-5.038461^{*}$ & 1.089215 & 0.000 \\
\hline I & $-1.167909^{*}$ & 0.5913282 & 0.048 \\
\hline Eg & $1.686485^{*}$ & 0.8247919 & 0.041 \\
\hline REER & $-0.4189804^{*}$ & 0.116535 & 0.000 \\
\hline Constanta & $203.5744^{*}$ & 11.24366 & 0.000 \\
\hline No. of observations & 110 & 110 & \\
\hline Prob > f & 0.0000 & 0.0000 & \\
\hline
\end{tabular}

Note : *significant $\alpha=5 \%$

\section{Discussion}

Everyone who can do work to produce goods or services to meet the needs of himself and the community is called a worker. Labor as a factor of production combined with other production factors, especially capital, will be able to generate an output in the form of goods and services. When workers do their job, the company will 
provide them wages. They use their wages to meet their basic needs, one of which is purchasing houses. House becomes a basic need since it becomes a place for humans to live (Agnew and Lyons, 2018). This condition thus requires the workers to set aside their incomes to meet their basic necessity, that is buying a house, which is noticed by property manufacturers and thereby driving up house prices. Meanwhile, in this study, the regression results of the number of workers variable indicated a negative and significant relationship with the RPPI, which are similar to the results of the study conducted by Tripathi (2019), although the results of this present study did not focus on the role of the number of workers on the RPPI. This can occur since not all workers buy houses. Even if the number of employments is high, there are new and old workers. The wages for new workers are commonly not high, so the workers prefer to buy other necessities rather than individual needs.

As another independent variable, interest rate is an economic variable that is always closely watched due to its extensive impact since a higher interest rate will slow down the real sector. It is worth noting that the interest rates of each bank are different, yet there is an interest rate ceiling set by the Central Bank to control the rates. However, this depends on the policies imposed by the bank itself and is not related to the bank's external factors. In this study, the regression results of the real interest rate variable revealed a significant and negative relationship with the RPPI, which is similar to the ones in the study conducted in Ontario by Nistor and Reianu (2018). Their study proved that the lower interest rates will boost individual purchasing power for a house since the interest that should be paid is lower. This consequently will increase housing loan demand which will also escalate house prices.

The regression results of the real economic growth variable depicted a positive and significant relationship with the RPPI, which are similar to the ones in the studies conducted by Vogiazas and Alexiou (2017), Li, et al. (2018), and Shiau, et al. (2018). Real economic growth has the highest impact compared to other variables because changes in income can represent an alteration in a person's ability to demand housing so that it also affects real estate prices. With the increasing income levels, people's standard of living will rise and the proportion of food consumption in their income will reduce. Similar to the development of income levels, people's demands to improve housing conditions and boost their investment will also be escalated. The results also indicated that disposable income has a high correlation with house prices since disposable income can reflect people's purchasing power for a house or an apartment. This positive relationship suggests that an increase in the ratio of credit to economic growth causes house prices to rise since the increasing availability of bank credit can escalate housing loan demand along with lower interest rates.

Bahmani-Oskooee and $\mathrm{Wu}$ (2018) argued that as the cost of imported goods increases, the inflationary effects of a depreciating currency can spread to the housing market and push house prices to be higher. For example, if the imported goods are in the form of construction, by increasing construction costs, depreciation can drive house prices higher. Meanwhile, in this present study, the regression results of the REER variable showed a significant yet negative relationship with the RPPI. These study results are similar to the one conducted by Asal (2019) in Sweden, even though the results of this present study did not focus on the role of the REER on the RPPI. He claimed that international trade has a crucial role in affecting the asset market dynamics of a country. When a shock occurs that causes the domestic currency to appreciate, a country with less favorable terms of trade will cause the price of local assets to fall, including housing assets.

\section{Conclusion And Suggestions}

The number of workers demonstrates a negative and significant effect on the Residential Property Price Index (RPPI) in five Asian emerging market countries in the first semester of 2009 (2009s1) until the second semester of 2019 (2019s2). This happens since the very high incomes do not increase the demand for housing. Also, not all workers buy houses since there are new and old workers. The wages for new workers are commonly not high, so the workers prefer to buy other necessities rather than individual needs like purchasing a house.

Similarly, the real interest rate negatively and significantly affects the RPPI in these five countries in the period. An increase in interest rates will increase household consumption, one of which is home consumption; the more people buying houses, the more house prices will increase. Meanwhile, economic growth shows a positive and significant impact on the RPPI in these five Asian emerging market countries in 2009s1-2019s2. With the increasing income levels, people's standard of living will also rise. Therefore, their demands to improve housing conditions and boost investment will also be escalated.

Eventually, the Real Effective Exchange Rate (REER) has a negative and significant influence on the RPPI in these five Asian emerging market countries in 2009s1-2019s2. It implies that the raise in the REER decreases the RPPI and vice versa. When a shock occurs that causes the domestic currency to appreciate, a country with less favorable terms of trade will cause the price of local assets to fall, including housing assets.

Since this study generated significant variables toward the RPPI, the central banks of respective countries are expected to be able to make the right policies, particularly in regulating interest rates. This way, a surge in house demand, which leads to a housing boom, will not occur. A larger working group population aged 1564 is considered favorable for a country since they boost its GDP. At the same time, they are demanding more houses. However, due to higher house prices, young people in this age group cannot achieve homeownership. Thus, the government is expected to carry out the suitable policy so that the number of productive workers increases. This way, they can contribute to increasing the economic growth of the five Asian emerging market countries.

Ultimately, further research regarding the determinants of the RPPI is expected to utilize more complete variables not only in terms of demand but also in terms of supply. Moreover, further research is also expected to employ data for a longer period of time to obtain more complex and accurate results.

\section{References}

[1] Agnew, K., \& Lyons, R. C. (2018). The Impact of Employment on Housing Prices: Detailed Evidence from FDI in Ireland. Regional Science and Urban Economics, 70, 174-189.

[2] Amador-Torres, J. S., Gomez-Gonzalez, O. E., \& SaninRestrepo, S. (2018). Determinants of Housing Bubbles' Duration in OECD Countries. International Finance, 118.

[3] Anundsen, A. K., Gerdrup, K., Hansen, F., \& KraghSørensen, K. (2016). Bubbles and Crises: The Role of House Prices and Credit. Journal of Applied Econometrics, 31(7), 1291-1311. 
[4] Asal, M. (2018). Long-run drivers and Short-term Dynamics of Swedish Real House Prices. International Journal of Housing Markets and Analysis, 11(1), 45-72.

[5] Bahmani-Oskooee, M., \& Wu, T.-P. (2018). Housing Prices and Real Effective Exchange Rates in 18 OECD Countries: A Bootstrap Multivariate Panel Granger Causality. Economic Analysis and Policy, 60, 119-126.

[6] Borjas, G. J. (2010). Labor Economics. Boston: McGraw-Hill/Irwin

[7] Brueggeman , W. B., \& Fisher, J. D. (2011). Real Estate Finance and Investments (fourteenth ed.). McGraw-Hill.

[8] Chi-WeiSu, Wang, X.-Q., Tao, R., \& Chang, H.-L. (2019). Does Money Supply Drive Housing Prices in China? International Review of Economics \& Finance, 60, 85-94.

[9] Cohen, V., \& Karpavičiūtè, L. (2017). The Analysis of the Determinants of Housing Price. Independent Journal of Management and Production, 8, 1.

[10] Dornbusch, Rudiger; Stanly Fischer, and Richard Startz. (2008). Macroeconomics (7 ed). Boston: Mc-Graw-Hill

[11] EE, L. (2013). Housing is the Business Cycle. The National Bureau of Economic Research.

[12] Gujarati , D. N. (2012). Dasar-Dasar Ekonometrika (5 ed.). Jakarta: Salemba Empat.

[13] Kaulihowa, T., \& Kamati , K. (2019). Determinants of House Price Volatility in Namibia. International Journal of Housing Markets and Analysis, 12(4), 807-823.

[14] Kishor, N. K., \& Marfatia, H. A. (2017). The Dynamic Relationship Between Housing Prices and the Macroeconomy: Evidence from OECD Countries. The Journal of Real Estate Finance and Economics, 54, 237268.

[15] Kok, S. H., Ismail, N. W., \& Lee, C. (2018). The Sources of House Price Changes in Malaysia. International Journal of Housing Markets and Analysis, 11(2), 335355.

[16] Latif, E. (2015). Immigration and Housing Rents in Canada: A Panel Data Analysis. Economic Issues, 20, 1.

[17] Leamer, E. E. (2015). Housing Really Is the Business Cycle: What Survives the Lessons of 2008-09? Journal of Money, Credit and Banking, 47(S1), 43-50.
[18] Li, Z., Razali, M. N., Fereidouni, H. G., \& Adnan, Y. M. (2018). Macro-economic Index Effect on House Prices in China. International Journal of Housing Markets and Analysis, 11(3), 453-475.

[19] Mankiw, N. G. (2010). Macroeconomics (Seventh ed.). New York: Pearson Education.

[20] Mishkin, F. S. (2015). Macroeconomics Policy and Practice (2 ed.). Pearson Education.

[21] Nicholson , W., \& Synder, C. (2012). Microeconomic Theory Basic Principles and Extensions (eleventh ed.).

[22] Nistor, A., \& Reianu, D. (2018). Determinants of Housing Prices: Evidence from Ontario Cities, 20012011. International Journal of Housing Markets and Analysis, 11(3), 541-556.

[23] Panagiotidis, T., \& Printzis, P. (2016). On the macroeconomic determinants of the housing market in Greece: a VECM approach. International Economics and Economic Policy, 13(3), 387-409.

[24] Pontiggia, D., \& Sivitanides, P. S. (2020). House Prices and Credit Cycles: The Case of Cyprus. ournal of Property Investment \& Finance, 38 (6), 539-550.

[25] Samuelson, P. A., \& Nordhaus, W. D. (2009). Economics (18 ed.). New York: McGraw-Hill.

[26] Strobel, J., Thanh, B. N., \& Lee, G. (2017). Effects of Macroeconomic Uncertainty and Labor Demand Shocks on the Housing Market. Real Estate Economics, 48, 345372.

[27] Sumer, L., \& Ozorhon , B. (2021). Investing in Gold or REIT Index in Turkey: Evidence from Global Financial Crisis, 2018 Turkish Currency Crisis and COVID-19 Crisis. Journal of European Real Estate Research, 24(1), 84-99.

[28] Tripathi, S. (2019). Macroeconomic Determinants of Housing Prices: A Cross Country Level Analysis. National Research University Higher School of Economics, 375.

[29] Vogiazas, S., \& Alexiou, C. (2017). Determinants of Housing Prices and Bubble Detection: Evidence from Seven Advanced Economies. Atlantic Economic Journal, 45(1), 119-131. 